\title{
HOLOCENE PALEO-SEA LEVEL IN SOUTHEASTERN BRAZIL: AN APPROACH BASED ON VERMETIDS SHELLS
}

Perla baptista de Jesus ${ }^{1}$, Fábio Ferreira dias ${ }^{1 *}$, Raquel de Azeredo Muniz ${ }^{2}$, Kita Chaves Damásio Macário ${ }^{1}$, José

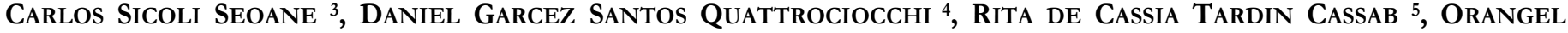
Aguilera ${ }^{1}$, Rosa Cristina Corrêa luz de Souza ${ }^{1}$, Eduardo Queiroz Alves ${ }^{6}$, Ingrid Silva Chanca ${ }^{7}$, Carla Regina Alves Carvalho ${ }^{1}$ and Julia CaOn Araujo ${ }^{1}$

1 Universidade Federal Fluminense, Programa de Pós-Graduação em Biologia Marinha e Ambientes Costeiros, Instituto de Biologia, Rio de Janeiro, Outeiro São João Batista, s/nº. Centro, Niterói, 24020-141 Rio de Janeiro, Brazil. Fax: + 552126292292. perlabtjs@hotmail.com, fabiofgeo@yahoo.com.br, kitamacario@gmail.com, orangel.aguilera@gmail.com,rcclsouza@yahoo.com.br, carlacarvalho@geoq.uff.br, G-julia.caon@yahoo.com.br

2 Instituto Mar Adentro, 22031-900Rio de Janeiro, Brazil. raqmuniz@hotmail.com

3 Universidade Federal do Rio de Janeiro, Departamento de Geologia, Instituto de Geociências, 21949-00 Rio de Janeiro, Brazil. cainho@geologia.ufrj.br

4 Universidade Federal Fluminense, Departamento de Química, Instituto de Química, 24020-150 Rio de Janeiro, Brazil. daniel_garcez@yahoo.com.br

5 Museu de Ciências da Terra, DNPM-Paleontologia, Departamento Nacional de Produção Mineral, $22290-240$ Rio de Janeiro, Brazil. rcassab@gmail.com

6 Oxford Radiocarbon Accelerator Unit, University of Oxford, Dyson Perrins Building, South Parks Road, Oxford, United Kingdom, OX13QY.qa.eduardo@gmail.com

7 Universidade Federal Fluminense, Departamento de Física, Instituto de Física, 24030-346 Rio de Janeiro, Brazil. ingrid.s.chanca@gmail.com

* Corresponding author, fabiofgeo@yahoo.com.br

Received on 9 February 2017

Accepted on 23 March 2017

\section{Editor:}

Maria Virginia Alves martins, Universidade do Estado do Rio de Janeiro
Received in revised form on 19 March 2017

SCREENED BY

$\checkmark$ iThenticate

\section{Citation:}

Jesus, P.B., Dias, F.F., Muniz, R.A., Macário, K.C.D., Seoane, C.S., Quattrociocchi, D.G.S., Cassab, R.C.T., Aguilera, O., Souza, R.C.C.L., Alves, E.Q., Chanca, I.S., Carvalho, C.R.A., Araujo, J.C., 2017. Holocene paleo-sea level in southeastern Brazil: an approach based on vermetids shells. Journal of Sedimentary Environments, 2 (1): 35-48.

between 6,300-4,500 cal yr BP, with a transgressive maximum of about $2.4 \mathrm{~m}$ above the present level at 4,700$4,500 \mathrm{cal} \mathrm{yr} \mathrm{BP}$, and a sea level drop from 4,500 cal yr BP until the present. Vermetidae (Mollusca: Gastropoda) as bioindicators. Chronology was established by radiocarbon Accelerator Mass Spectrometry technique. Three evolutionary stages of sea level were established: sea-level lower than the current one between 8,148-6,300 cal yr BP, a rising of sea level
Keywords: Sea level. Petaloconchus. Paleoenvironment; radiocarbon. Quaternary. South Atlantic Ocean. Armação dos Búzios. 


\section{Introduction}

During the Quaternary, sea level changes were largely caused by melting and advances of ice sheets and thermal expansion of the oceans due to the climatic changes (Dasgupta and Meisner, 2009). Throughout the Holocene, paleo-sea level variations included eustasy (global sea level change), tectono-eustasy, glacial eustasy and geoidal eustasy causing alterations in the volume of oceanic basins and the sea water level (Mörner, 1984). During the Holocene Climatic Optimum: there was a period with warmer temperatures than those prevailed nowadays, with the consequent increase of heat and reduction of polar ice caps and; there was a rise in ocean levels between 2 to $5 \mathrm{~m}$ above the current one, at about 5,000 years ago (Nakada et al., 1991; Grossman and Fletcher, 1998). This climatic event was followed by a cooling period that led to a sea level drop.

The mean sea level (MSL) varies on global (eustatic level) and regional (relative level) scales (Williams, 2013). It is possible to find many different curves representing sea level change in different places of the world. Kaye and Barghoorn (1964) studied sea level changes in the last 14,000 years, at the coast of Boston (MA, USA). These authors observed that in the early Holocene (10,000 years BP) the sea level was below the current -21.33 meters, rising continually up to 3,000 years BP. Close to Boston, in the Gulf of Maine, Kelley et al. (2013) reported an increase in the sea level from 11,500 years BP to 7,500 years BP.

Behre (2007) tried to reconstruct a curve for the German coast of the North Sea during the last 10,000 years. For this purpose, this author utilized data from several works. The resulting curve showed seven marine regressions during the Holocene. In general, the sea suffered sharp increase about 5,000 years BC, giving rise to significant oscillations. This curve was questioned by Bungenstock and Weerts (2010), who suggested the impossibility of representing changes in sea level during the Holocene in a single curve for a large area. Thus, Bungenstock and Weerts (op. cit.) divided the German coast in five sections according to the influence of the tide and built curves with different oscillations due to local influences.

Several studies have been conducted in the Southern Hemisphere aiming to reconstruct past sea levels during the Holocene (e.g. Chappell, 1983; Matsushina et al., 1984; Flood and Frankel, 1989; Isla, 1989; Pirazzoli, 1991; Beaman et al., 1994; Baker and Haworth, 2000; Ramsay and Coper, 2002; Cavallotto et al., 2004; Sloss et al., 2007; Lewis et al., 2013; Martinez and Rojas, 2013). In Brazil, these studies have mainly been conducted since the 1970's and the vertical amplitudes ranged from 2 to $5.3 \mathrm{~m}$ (e.g. Martin and Suguio, 1975; Suguio et al., 1985, 2013; Dominguez et al., 1990;
Martin and Suguio, 1992; Angulo and Lessa, 1997; Angulo et al., 2002, 2006; Dias, 2009; Castro et al., 2014).

There are several types of proxies used to reconstruct the paleo-sea level, comprising geological (sandy deposits and outcrop of beach rocks), archaeological (mainly exemplified by shell mound sites), and biological (fossilized organisms over the shore, as barnacles, coral exoskeletons, sea urchin burrows, calcareous algae and mollusk shells) indicators (Lambeck et al., 2010). Biological indicators, particularly sessile organisms as worm snails Vermetidae (Mollusca: Gastropoda), have been largely used in many studies about relative sea level change (Van Andel and Laborel,1964; Suguio et al., 1985, 2013; Laborel, 1986; Pirazzoli, 1991; Laborel and Laborel-Deguen, 1994, 1996; Pirazzoli et al., 1996; Angulo and Lessa, 1997; Angulo et al., 1999, 2006; Antonioli et al., 1999; Baker and Haworth, 2000; Lambeck et al., 2004; Vescogni et al., 2008; Dias, 2009), because they are excellent proxies of former sea levels. They are able to provide reliable information about mean sea level position in the past due to their short lifetimes (Laborel, 1986; Laborel and Laborel-Deguen, 1994, 1996; Pirazzoli et al., 1996; Angulo et al., 2006).

Vermetids are gastropods that have elongated tubular shells, protruded from the substrate and attached to a solid basis (Keen, 1961; Safriel, 1975; Bandel and Kiel, 2000). These organisms commonly live in tropical and subtropical waters, between latitudes $44^{\circ} \mathrm{N}$ and $44^{\circ} \mathrm{S}$ (Safriel, 1975; Bieler and Petit, 2011). In Brazil, there are 16 species of these gastropods (Spotorno et al., 2012) but according to Laborel (1977) these organisms are scarce or rare along the Brazilian coast. However, these gastropods are found building reefs in Angra dos Reis (Rio de Janeiro, Brazil) (Breves-Ramos, 2012). Only two of them are described as fossils in Brazil: Petaloconchus varians (Angulo et al., 1999, 2006; Dias, 2009) and Dendropoma irregulare (Angulo et al., 2013). Concerning Armação dos Búzios (Rio de Janeiro, Brazil), only records of P. varians have been described by Martin et al. (1997) and Dias (2009).

Although research on sea level changes in Cabo Frio and Armação dos Búzios regions (Rio de Janeiro, Brazil) showed significant changes in sea level during the Holocene (Dias, 2009; Freitas, 2011; Cunha et al., 2012; Castro et al., 2014), more data are necessary to reconstruct sea level curves for the area. Therefore, the present work aims to investigate the relative sea level changes in the southeastern Brazilian coast during the Holocene. 


\subsection{Study area}

The study area is located in Armação dos Búzios city (north of Rio de Janeiro state, Brazil (Fig. 1). It is characterized by crystalline rocky basement overlapped by the siliciclastic Barreiras Formation and marine Quaternary deposits (Martin et al., 1997; Morais et al., 2006). The coastal plain, the marginal lagoons and bays were sources of unsorted sands and reworking materials that characterized lakes and marsh sediments related to sea level changes (Martin et al., 1997).

Regarding the geomorphology, Armação dos Búzios is mainly a large and flat area with other landscape features such as low hills (generally high between 40 and $100 \mathrm{~m}$ ), high hills (100 and $300 \mathrm{~m}$ ), both with declivity $>15 \%$, and hills with declivity between $5 \%$ and $15 \%(<40 \mathrm{~m})$.

Savi (2007) reported an average tidal range of about 1.0 $\mathrm{m}$, based on tide gauge records of the last 18 years at Porto do Forno, nearby Arraial do Cabo (Rio de Janeiro, Brazil).

The annual total rainfall is about $800 \mathrm{~mm}$ (Nimer, 1989). Barbiére (1984) classified the climate as semi-arid and, according to Martin et al. (1997), this microclimate is associated to a reduced local rainfall rate and the seasonal presence of cold waters from upwelling. The sky is clear most of the time, with dominant northeastern winds, varying from north to east, under the influence of the South Atlantic Anticyclone (SAA).

The local Sea Surface Temperature (SST) is below $19^{\circ} \mathrm{C}$, according to the Advanced Very High Resolution Radiometer (AVHRR) sensor photo image map (Kampel, 2002). A low SST is related to an upwelling phenomenon in the region of Cabo Frio, as a result of the displacement of surface water mass (Tropical Waters - TW). The northeastern trade winds associated with the coastal shape, composing a low pressure area that enables the South Atlantic Central Waters (SACW) to outcrop (Mesquita et al., 1979).

\section{Material and methods}

\subsection{Altimetry survey of indicators}

The altimetry survey of biological indicators' level was performed in static mode using two ZENITE receivers in relative mode (ZENITE 2, GTR-Z2 model). In relative positioning, the coordinates are determined in relation to a referential materialized through one or more stations with known coordinates. In this case, it is necessary that at least two receivers collect data from at least two satellites simultaneously, where one of the receivers must occupy the station with known coordinates, referred to as the reference station or base station (code station 93520, in Angra dos Reis and code station 91970, in Armação dos Búzios). The nearest station choice depended on a geodetic database check, on the IBGE website (Instituto Brasileiro de Geografia e Estatística, 2014), choosing the SAT GPS option.

GTR -Processor was GNSS (Global Navigation Satellite System) Post-Processing software that provided a reliable and efficient solution to improve the accuracy of survey data. The static mode accuracy is $2.5 \mathrm{~mm} \pm 0.5 \mathrm{ppm}$.

The ellipsoidal heights are transformed in orthometric heights using the program MAPGEO that converts the data of the GPS receivers in heights referring to the sea level.

\subsection{Radiocarbon analysis}

Chronology was determined by the ${ }^{14} \mathrm{C}$ Accelerator Mass Spectrometry $\left({ }^{14} \mathrm{C}-\mathrm{AMS}\right)$ method, at the Radiocarbon Laboratory of the Universidade Federal Fluminense (LAC UFF). Samples underwent physical and chemical pretreatments to remove contaminants on the surface layer of the shells, originated from secondary carbonates. Samples were observed under microscope and scraped to remove apparent contamination.

Sub-samples of about $20-40 \mathrm{mg}$ were cut with a razor blade. In test tubes, specific amounts (between $1.9 \mathrm{ml}$ and $3.4 \mathrm{ml}$ ) of $0.1 \mathrm{M}$ hydrochloric acid $(\mathrm{HCl})$ were added to etch about $50 \%$ of the sample weight. Tubes were evacuated and phosphoric acid $\left(\mathrm{H}_{3} \mathrm{PO}_{4}\right)$ was inserted through a septum for carbon dioxide $\left(\mathrm{CO}_{2}\right)$ extraction. The gas was then purified and graphitized following standard procedures (Macario et al., 2013, 2015). Measurement was performed in a $250 \mathrm{kV}$ NEC single-stage accelerator mass spectrometer.

Conventional ages were calibrated in OxCal software (Bronk Ramsey, 1995), 4.2 version, using the marine calibration curve Marine13 (Reimer et al., 2013), and $\Delta \mathrm{R}=$ $32 \pm 44{ }^{14} \mathrm{C}$ yr (Alves et al., 2015).

\subsection{Sea level changes representation}

A graph representing the paleolevels and their oscillations was constructed by using the data on altitude (orthometric heights) and indicators of age, in Excel software (2010 version), with calibrated age averages in the horizontal axis (x) and sample altitudes on the ordinate axis (y). For the establishment of the trend line curve, a fourth-degree polynomial was used. 

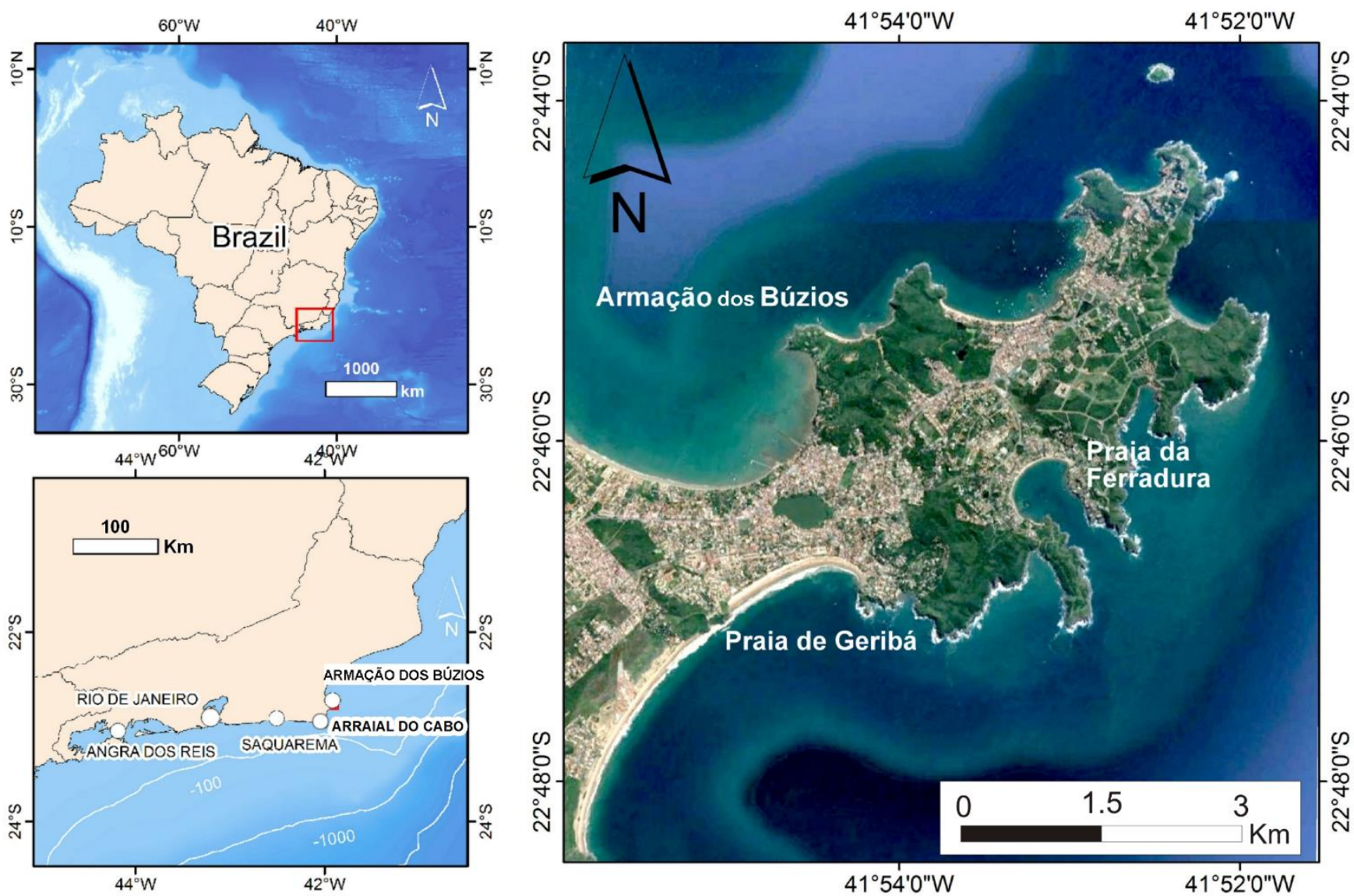

Fig. 1. Location of the study site in Armação dos Búzios coast.

\subsection{Paleoenvironmental reconstitution}

A Digital Terrain Model (DTM) was created from municipal official topographic data of Armação dos Búzios, on scale of 1: 10.000, with UTM projection, zone 24S, datum SAD-69 and bathymetric data of the area, assigned by Brazilian Navy, using ArcGIS software 10 version.

Then, a 3-D model was built using ArcScene software10 version, to make simulations of the evolution of the paleoenvironment along the Holocene.

The reconstruction was based on sea level changes representation data, analyses of field evidences and previous results from the literature (Martin et al., 1997; Dias, 2009; Freitas, 2011) calibrated with similar parameters to match those of the present research.

\section{Results and discussion}

\subsection{Altimetry survey of indicators}

The orthometric heights of living vermetids found attached to Angra dos Reis rock shores were about $-0.4 \mathrm{~m}$ (Tab. 1). Dias (2009) found higher values (1 m high) in Búzios Island (Angra dos Reis) as this area is likely more exposed and the wave dynamics influence the life range of these species, as proposed by Laborel (1986). Therefore, we used an uncertainty estimation based on local hydrodynamics, where $\pm 0.5 \mathrm{~m}$ corresponds to sheltered areas and $\pm 1.0 \mathrm{~m}$ to the most exposed areas, for the calibration of subfossil vermetid heights. The latter are commonly found inside rocky crevices, protected from the wave action. This shielding explains their long-term presence and is in agreement with Angulo et al. (1999) and Ribeiro et al. (2011). 
Tab. 1. Orthometric heights of living vermetids found attached to Angra dos Reis rock.

\begin{tabular}{llcc}
\hline Place & $\begin{array}{c}\text { Geographical } \\
\text { coordinates }\end{array}$ & $\begin{array}{c}\text { Ellipsoidal height } \\
\text { (m) }\end{array}$ & $\begin{array}{c}\text { Orthometric height } \\
\text { (m) }\end{array}$ \\
\hline Brandão Island & $\begin{array}{c}-23^{\circ} 01^{\prime} 35.009^{\prime \prime} \\
-44^{\circ} 23^{\prime} 55.174^{\prime \prime}\end{array}$ & -4.964 & -0.404 \\
& $-23^{\circ} 00^{\prime} 18.299^{\prime \prime}$ & & -0.411 \\
Secreta Beach & $-44^{\circ} 26^{\prime} 30.458^{\prime \prime}$ & -4.971 & \\
& $-23^{\circ} 01^{\prime} 8.433^{\prime \prime}$ & & -0.434 \\
\hline
\end{tabular}

Subfossil vermetids heights from 10 different locations (Fig. 2) ranged from 0.24 to $2.25 \mathrm{~m}$ above current sea level and an uncertainty estimate from \pm 0.5 to $\pm 1 \mathrm{~m}$ (Tab. 2).

To determine the vermetid paleolevels at the time they were still alive, studies such as Angulo et al. (1999, 2002), Ribeiro et al. (2011) used the relation between the life ranges of these gastropods and the polychaetes Phragmatopoma lapidosa, since the upper limit of the latter corresponds to the lower limit of the former. However, since this kind of annelids are not present in any Armação dos Búzios beaches and their vertical variation may be different from the vermetids (Angulo and Souza, 2014), in the present work we used the closest gastropod reef formation, Angra dos Reis, as applied in the study of Dias (2009).

\subsection{Radiocarbon results}

Vermetids are filter feeding organisms; therefore, their isotopic concentrations reflect the surficial ocean isotopic composition due to the marine reservoir effect (Stuiver et al. 1986; Ascoughet al. 2005). When dealing with marine samples' radiocarbon results, it is necessary to calibrate them, taking into account not only the most recent marine calibration curve Marine13 (Reimer et al., 2013), but also the local offset $\Delta \mathrm{R}$ relative to the area where the specimens were collected. Very few studies on the local reservoir effect on the Brazilian coast are available and the most recent recommendation for the mean value is $\Delta \mathrm{R}=32 \pm 44{ }^{14} \mathrm{C} \mathrm{yr}$ (Alves et al., 2015). Radiocarbon results are presented in Table 3.

Tab. 2: Subfossil vermetids' heights from 10 different locations in Armação dos Búzios.

\begin{tabular}{lccc}
\hline \multicolumn{1}{c}{ Place } & Ellipsoidal height $(\mathrm{m})$ & Orthometric height $(\mathrm{m})$ & Uncertainties $(\mathrm{m})$ \\
\hline Ferradura & -5.700 & 0.243 & \pm 0.5 \\
Foca 1 & -4.845 & 1.098 & \pm 1.0 \\
Foca 2 & -4.505 & 1.438 & \pm 1.0 \\
Brava 1 & -4.575 & 1.368 & \pm 1.0 \\
Brava 2 & -4.321 & 1.622 & \pm 1.0 \\
JoãoFernandes & -4.720 & 1.223 & \pm 0.5 \\
Geribá & -4.684 & 1.259 & \pm 1.0 \\
Tartaruga & -5.355 & 0.588 & \pm 0.5 \\
Azeda & -4.917 & 1.026 & \pm 0.5 \\
Caravelas & -3.692 & 2.251 & \pm 1.0 \\
\hline
\end{tabular}


Tab. 3. Results of subfossil vermetids' radiocarbon.

\begin{tabular}{|c|c|c|c|c|}
\hline LACUFF Code & Place & $\begin{array}{c}\text { Geographical } \\
\text { coordinates }\end{array}$ & $\begin{array}{c}\text { Conventional } \\
\text { age (yr BP) }\end{array}$ & $\begin{array}{l}\text { Calibrated } \\
\text { age (yr BP) }\end{array}$ \\
\hline 140188 & Ferradura & $\begin{array}{l}-22^{\circ} 46^{\prime} 24.486^{\prime \prime} \\
-41^{\circ} 53^{\prime} 6.618^{\prime \prime}\end{array}$ & $1397 \pm 81$ & $1137-752$ \\
\hline 140189 & Foca 1 & $\begin{array}{l}-22^{\circ} 45^{\prime} 52.642^{\prime \prime} \\
-41^{\circ} 52^{\prime} 40.170^{\prime \prime}\end{array}$ & $1652 \pm 82$ & $1357-1002$ \\
\hline 140190 & Foca 2 & $\begin{array}{l}-22^{\circ} 45^{\prime} 52.524^{\prime \prime} \\
-41^{\circ} 52^{\prime} 40.274^{\prime \prime}\end{array}$ & $1918 \pm 72$ & $1627-1293$ \\
\hline 140191 & Brava 1 & $\begin{array}{l}-22^{\circ} 45^{\prime} 17.709^{\prime \prime} \\
-41^{\circ} 52^{\prime} 7.590^{\prime \prime}\end{array}$ & $3139 \pm 64$ & $3097-2753$ \\
\hline 140192 & Brava 2 & $\begin{array}{l}-22^{\circ} 45^{\prime} 19.346^{\prime \prime} \\
-41^{\circ} 52^{\prime} 8.871^{\prime \prime}\end{array}$ & $2736 \pm 68$ & $2675-2299$ \\
\hline 140193 & JoãoFernandes & $\begin{array}{l}-22^{\circ} 44^{\prime} 24.143^{\prime \prime} \\
-41^{\circ} 52^{\prime} 25.820^{\prime \prime}\end{array}$ & $2094 \pm 60$ & $1820-1517$ \\
\hline 140194 & Geribá & $\begin{array}{l}-22^{\circ} 46^{\prime} 57.915^{\prime \prime} \\
-41^{\circ} 54^{\prime} 57.525^{\prime \prime}\end{array}$ & $1968 \pm 31$ & $1610-1400$ \\
\hline
\end{tabular}

\subsection{Sea level changes representation}

The ages presented by Dias (2009) were recalibrated with the newest calibration curve to compare with the results of the present work and the construction of a new curve for Cabo Frio, Arraial do Cabo and Armação dos Búzios region, from 21 paleolevels (Fig. 3). The results from Dias (2009) are represented by triangles and those from the present work are represented by squares. Horizontal error bars are standard deviation ranges from calibrated mean ages and vertical error bars represent uncertainty in heights relative to paleo-sea level varying between $\pm 0.5 \mathrm{~m}$ and $\pm 1.0 \mathrm{~m}$, based on local hydrodynamics.

In the constructed curve, two shell paleolevels from Dias (2009) were plotted in the graph to confirm that the paleo-sea level was consistently above these points. These indicators only show that the paleolevel was higher than a certain value (Angulo et al., 2002), because they are organisms living in subtidal; therefore, they should only be below the trend line that represents the average level.

In order to establish the trend line, we used the $4^{\text {th }}$ degree polynomial, which was the best-fit linear trend, taking into account its error bars and the positive correlation between the factors. The determination coefficient $\left(\mathrm{R}^{2}=\right.$ $0.79)$ indicated that the proposed model was adequate to describe the phenomenon.

The constructed curve shows similarity with the Southern Hemisphere ones, without oscillations after its transgressive maximum, smoothly decreasing until the current zero (e.g. Chappell, 1983; Flood and Frankel, 1989; Isla, 1989;
Pirazzoli, 1991; Beaman et al., 1994; Cavallotto et al., 2004; Lewis et al., 2013; Martinez and Rojas, 2013) (Fig. 4.A, F and G).

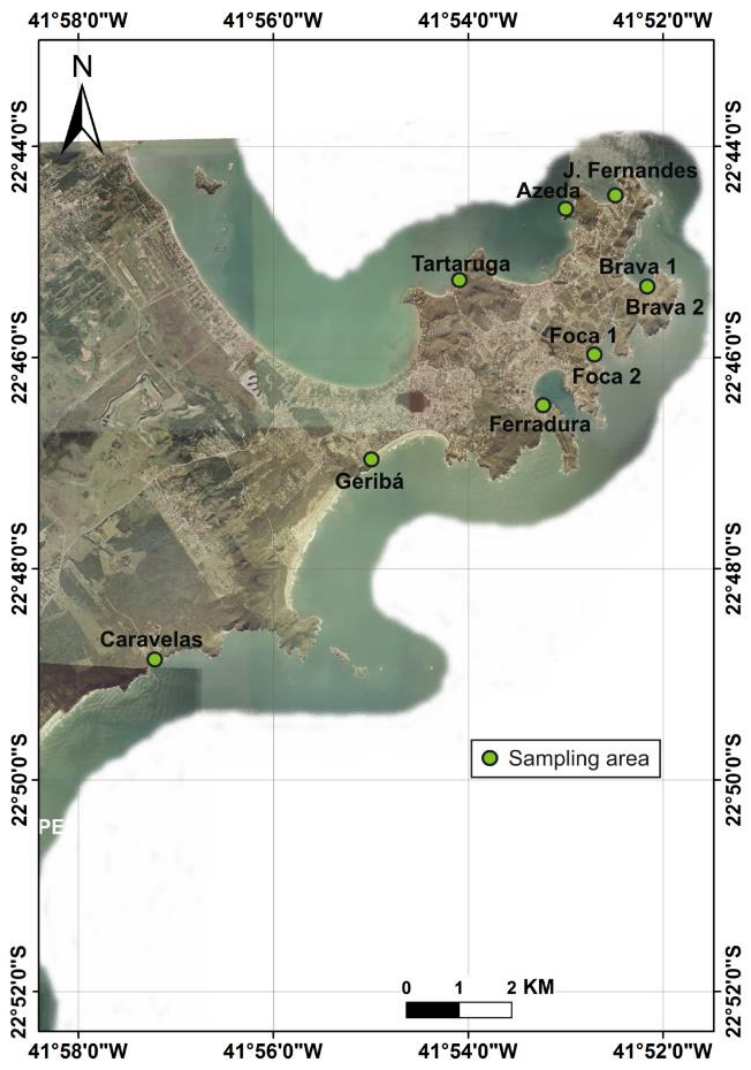

Fig. 2. Location of visited places where bioindicators were found. 
The shape and amplitude of this new curve are also in accordance with many other curves for Brazil as the ones developed by Angulo and Lessa (1997), Angulo et al. (2006), Dias (2009) and Castro et al. (2014) (Fig. 4.B-E).

However, when compared to the curves shown by Suguio et al. (1985) for several segments of the Brazilian coast, oscillations were not observed after the maximum reached. The maximum height observed by Suguio et al. (1985) was about $5 \mathrm{~m}$. Besides Suguio et al. (op. cit.), the constructed curve in this study also disagrees with the one presented by Dominguez et al. (1990), which shows three transgressive maxima (Fig. 5).

Castro et al. (2014) constructed a curve representing the sea level changes on the shore of the Rio de Janeiro state by using geological and biological data. Twenty-nine data were presented in this study, 17 from Dias (2009), 4 from Castro and Suguio (2011), 1 from Cunha et al. (2012) and 2 from Mansur et al. (2011), out of which only 14 data were used to establish the curve and it was not explained which criteria were used in selecting such data (Fig. 4.C).

In this study, the authors present two samples dated by Mansur et al. (2011), one related to the carbonate cement from Jaconé (Saquarema-RJ) beach rock and the other to shell fragments of the same deposit, having heights of $0.0 \mathrm{~m}$ and $0.5 \mathrm{~m}$, respectively. However, Mansur et al. (op. cit.) did not shown the altitudes of these samples in their work and Castro et al. (2014) did not present the station used for GPS positioning, making impossible to know the distance between that station and the study area. Carmo (2014) correlated the age found by Mansur et al. (2011) and height of that cement, with the sea level change curve proposed by Dias (2009), noting that the height of the sea level in that time would be 1.4 to $1.9 \mathrm{~m}$ above the current level, disagreeing with the height presented by Castro et al. (op. cit.), $-0.5 \mathrm{~m}$, wherein the trend line of the curve would be higher.

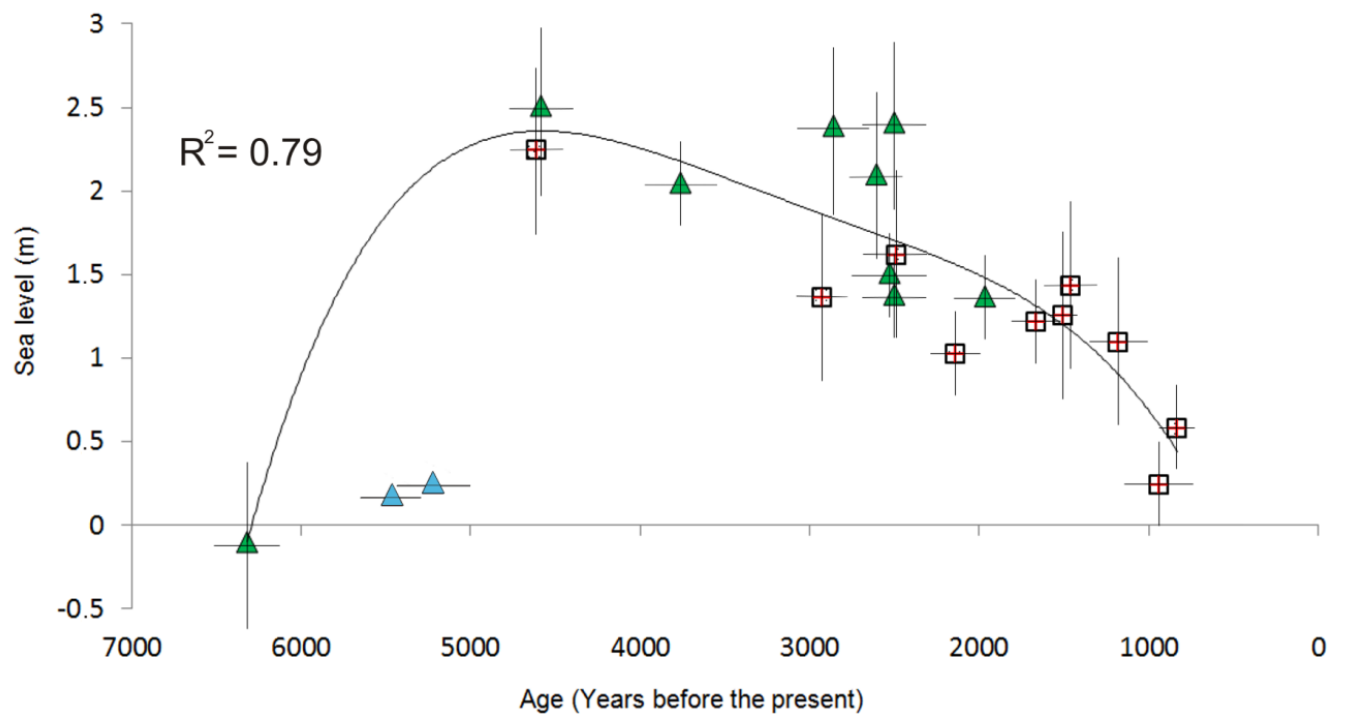

Fig. 3. New curve of relative sea level changes in Cabo Frio, Arraial do Cabo and Armação dos Búzios region. This curve was based on 21 paleolevels:10 paleolevels of this study (squares) and 11 paleolevels of previous research (Dias, 2009) (triangles). The shell samples are represented by blue triangles.

Still on the curve proposed by Castro et al. (2014; Fig. 4C), the authors presented four beach rocks referring to Castro et al. (2012), data published primarily by Castro and Suguio (2011), where it is possible to notice the conflicting information between the two studies. Two beach rock samples of those four ones (Castro et al., 2012) are shown in the curve proposed by Castro et al. (2014; Fig. 4C), where their ages were contemporary with those mentioned by Castro and Suguio (2011).
However, the sample \#22 is presented with 7,910-7,690 cal yr BP, while in the study of Castro et al. (2012) it has been reported with an age of 12,910-12,690 cal yr BP. Moreover, sample \#23, reported in the curve of Castro et al. (2014) with an age of 3,130-2,860 cal yr BP, appeared with 13,130-12,860 cal yr BP in the previous study. These data, used for construction of the curve, may have allowed the establishment of different shapes, amplitudes and oscillations. 


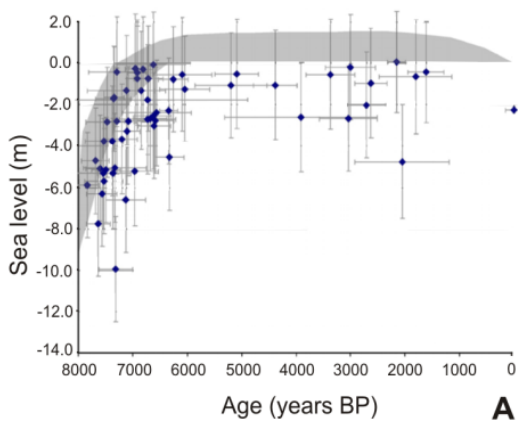

Northern Australia

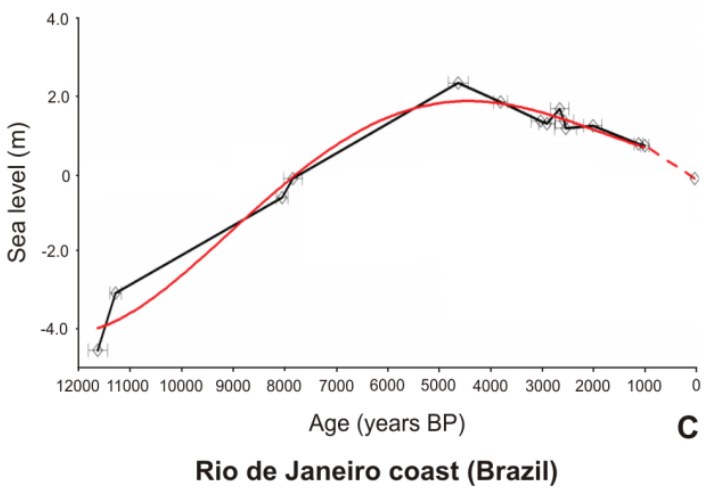

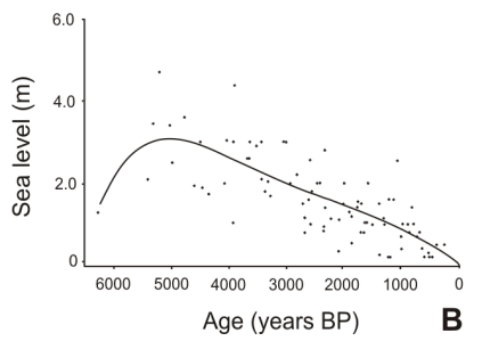

Brazilian coast

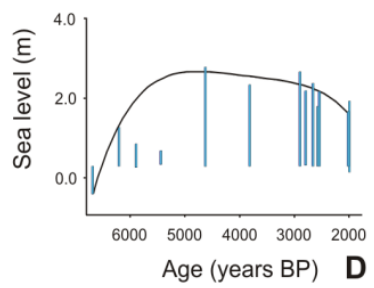

North of Rio de Janeiro state (Brazil)

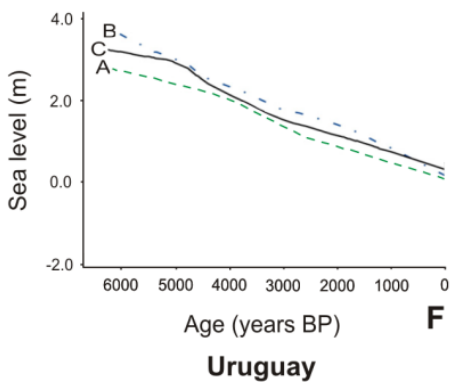

- Indicators derived from vermetid radiocarbon dates

- Mangrove

Minimum sea level inferred from composite paleontological data

$\Delta$ Minimum paleolevel inferred from mollusc shells

$\longrightarrow$ Calibrated data sample

Polynomial $4^{\text {th }}$ line

----- Tendence line

-. - . C Curve based on composite literature

- - - - Curve using the own data
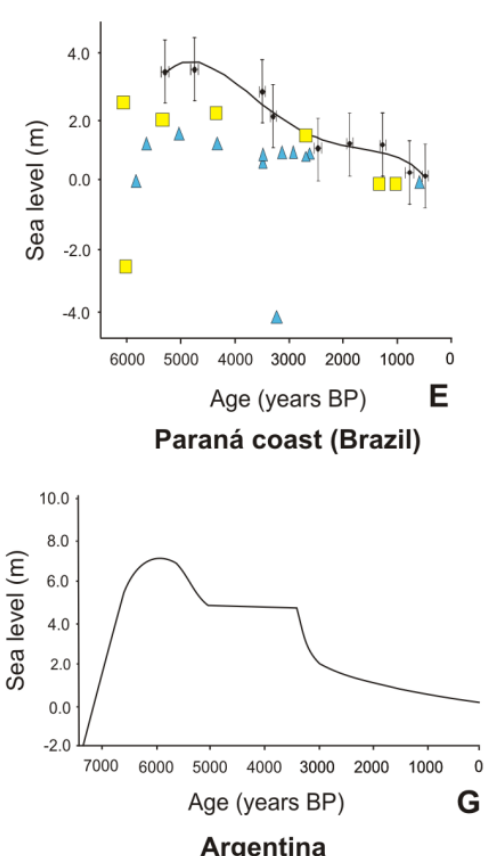

Fig. 4. Sea level curves distributed in the southern hemisphere, including Brazil. A: Northern Australia, modified from Lewis (2013); B: curve constructed from published vermetids along the Brazilian coast, modified from Angulo and Lessa (1997); C: Rio de Janeiro coast, modified from Castro et al. (2014); D: Cabo Frio - Armação dos Buzios (RJ); modified from Dias (2009); E: Paraná coast, modified from Angulo et al. (2002); F: Uruguay, modified from Martinez and Rojas (2013); G: Argentina, modified from Cavallotto et al. (2004).

\subsection{Landscape reconstruction during the Holocene}

Based upon results from literature and from the present study, three paleoenvironmental stages in Armação dos Búzios were established: sea level lower than the current one between 8,148-6,300 cal yr BP, rising of sea level between 6,300-4,500 cal yr BP and lowering of sea level from 4,500 cal yr BP to the present.

3.4.1 Phase 1: Sea level lower than the current one $(8,148-6,300 \mathrm{cal}$ yr BP)

In the interval 8,148-7,666 cal yr BP, beaches were in a more external position, towards the ocean. At the place where today is the Manguinhos bight, there was an outer barrier-lagoon system (Fig 6.1A). Geribá lake was not present yet (Fig. 6.1B) and what is area occupied by Ferradura lake today, it was a coastal plain, where there was a paleolake (Fig. 6.1C and 6.2) (Freitas, 2011).

The sea level was lower than the present one as suggested by the age of Ferradura lake sample (8,148-7,666 cal yr BP) from Freitas (2011). The author classified this sample as continental because of the current lake sediment characteristics and the absence of marine evidence. Freitas (op. cit.) described the palynology record, indicating that it is a paleoenvironment dominated by open sand ridge shrubtree vegetation growing on the barrier. 


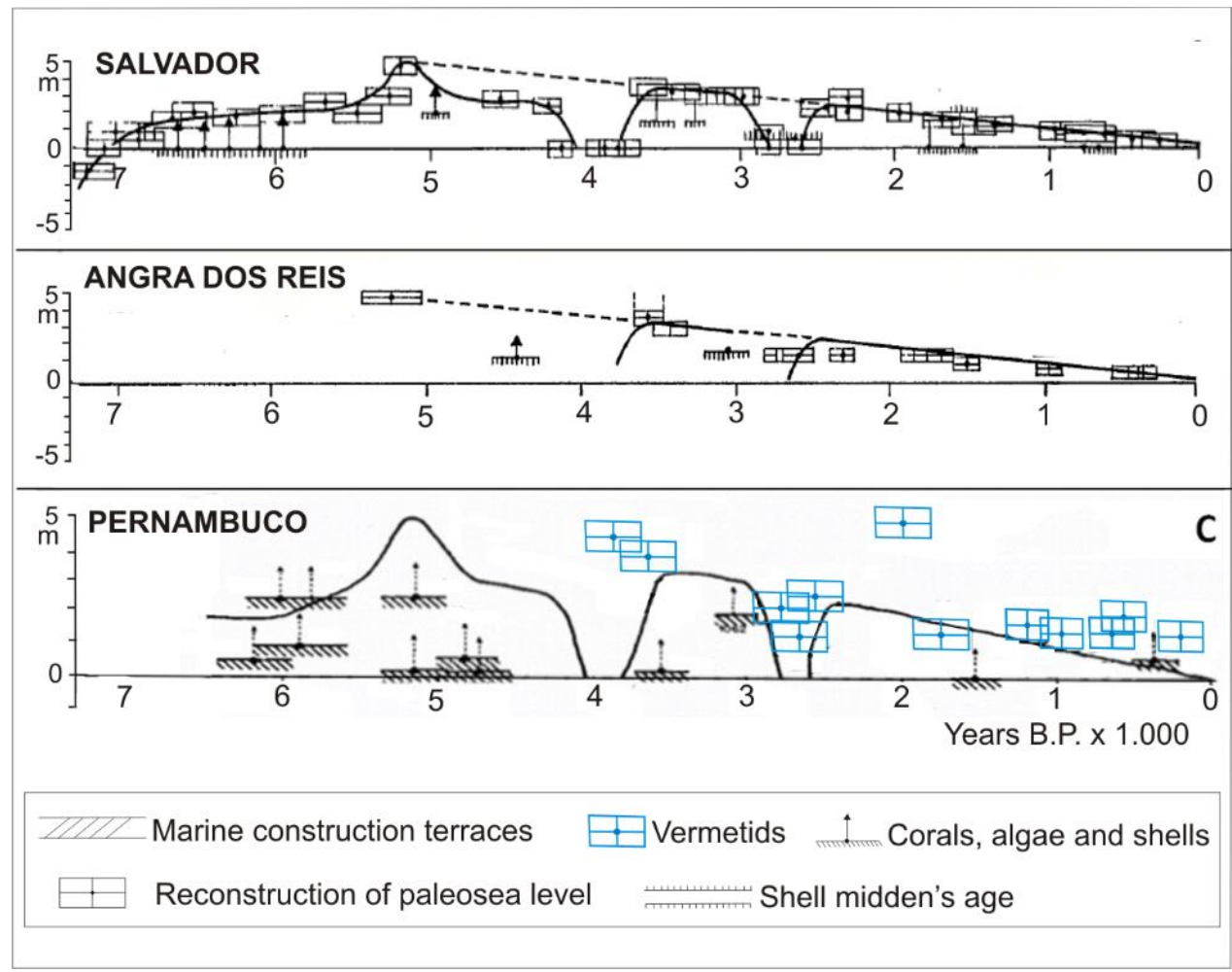

Fig. 5. Sea level curves for the coast of (A) Salvador, (B) Angra dos Reis, presented by Suguio et al. (1985) and (C) Pernambuco, presented by Dominguez et al. (1990).

There is evidence of the occurrence of a paleolagoon already established before the sea level exceeded the current position in Manguinhos bight, and of shells with age of 7,055-5,565 cal yr BP found by Martin et al. (1997), being the oldest record with evidence of a lagoon nearby.

The charcoal sample from Peró beach, Cabo Frio city, located $5 \mathrm{~km}$ from the study area, at about $-0.10 \mathrm{~m}$ and dated with 6,440-6,200 cal yr BP, by Dias (2009), demonstrates that sea level was lower than the current one. According to the trend line of sea level curve constructed for the region, it is possible to suggest that the sea exceeded the current zero at about 6,300 cal yr BP.

\subsubsection{Phase 2: Sea level rising (6,300-4,500 cal yr BP)}

The phase 2 started after the sea level exceeded the current zero, elevating to reach its transgressive maximum in 4,700-4,500 cal yr BP. Because of the sea level rising, the barrier situated in Manguinhos bight migrated towards the continent (Fig. 6.3A and 6.4A), beyond water body expansion where the paleolagoon was placed (Fig. 6.3B). The beaches have also been displaced towards the mainland and
Ferradura paleolake expanded, being attached to the sea and becoming a paleolagoon (Fig. 6.3C).

As the sea level rose, there was the drowning of coastal plains, where two parts of the area got disconnected, one at Ferradura lake (Fig. 6.4B) and another at Tucuns (Fig. 6.4C), and also the flooding of Geribá lake area (Fig. 6.4D).

After surpassing the current zero, the sea level kept rising until it reached its maximum, between 4,700-4,500 cal yr BP. The highest sample corresponds to the maximum transgressive period: 4,773-4,400 cal yr BP (Dias, 2009). The heights during this phase varied between 0 and $+2.51 \mathrm{~m}$.

Several lagoon systems were already established before the maximum sea level as evidenced by the shells dated at Manguinhos bight by Martin et al. (1997): 6,515-5,471 cal yr BP and 6,604-5,565 cal yr BP and; Dias (2009): 6,418-6,268 cal yr BP.

Dias (2009) dated shells (6,418-6,268 cal yr BP), higher than $0.50 \mathrm{~m}$ and charcoal sample dated $(6,440-6,200 \mathrm{cal} \mathrm{yr}$ $\mathrm{BP})$, with $-0.10 \mathrm{~m}$. These data may explain the fact that the northern portion of the study site has flooded before the southern portion, due to the topography. 

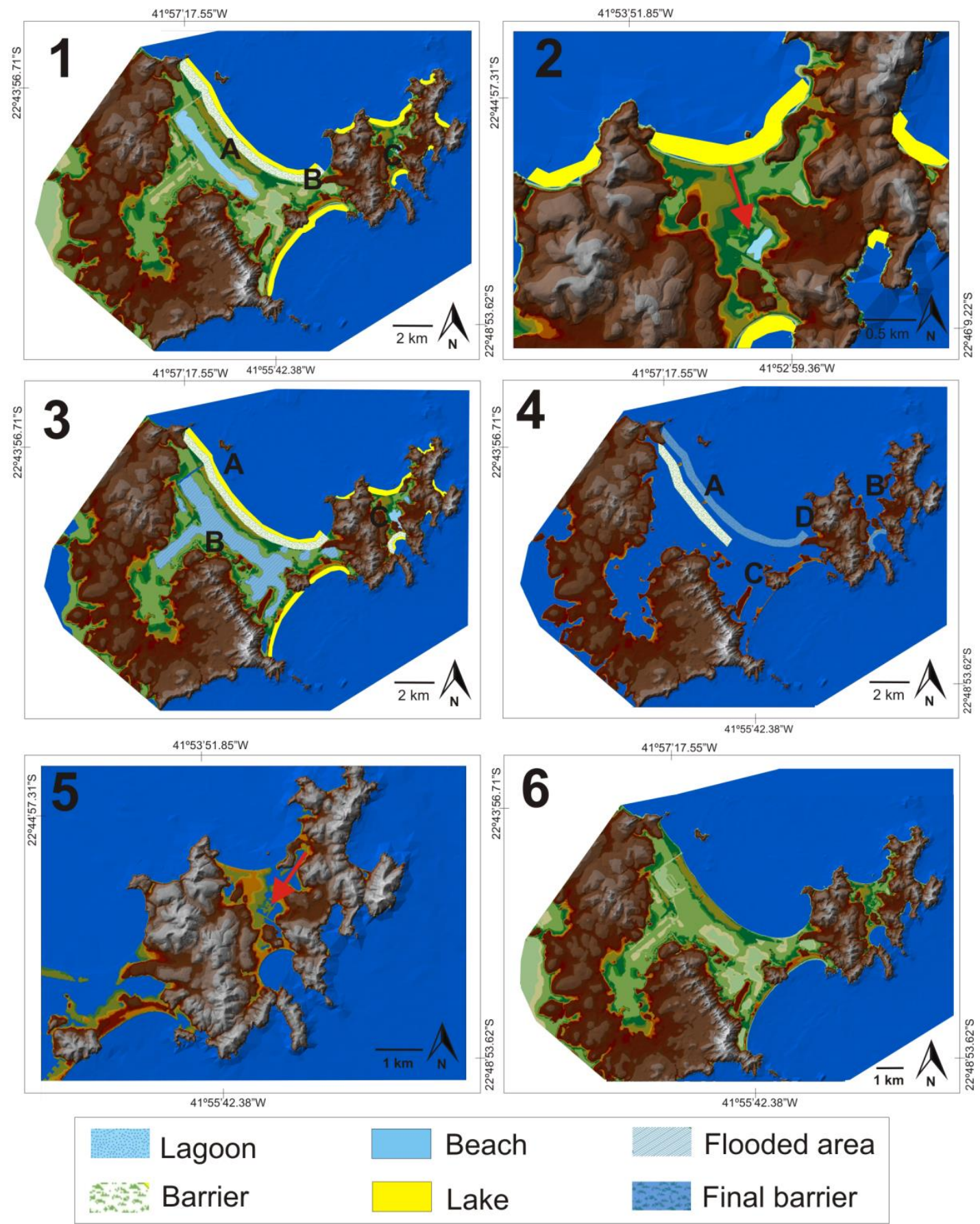

Fig. 6. Map 1: Armação dos Búzios Palaeoenvironmental reconstitution corresponding to Phase 1. (A): Manguinhos bight; (B): Geribá; (C): Ferradura; Map 2: Details of reconstructed Ferradura paleolake (indicated with arrow); Map 3: Reconstitution corresponding to Phase 2. (A): Manguinhos bight; (B): Flooded area where the Manguinhos paleolagoon was localized; (C): Ferradura paleolagoon; Map 4: Reconstitution corresponding to Phase 2. (A): Manguinhos bight; (B): Ferradura; (C): Tucuns; (D): Geribá; Map 5: Reconstitution corresponding to Phase 3, highlighting the beginning of the transformation of Ferradura paleolagoon into a lake; Map 6: Reconstitution corresponding to Phase 3, featuring the current environment. 
Because of the sea level rising, the barrier located in Manguinhos bight migrated towards the mainland, as explained by the Bruun rule (Bruun, 1962). The beaches also suffered displacement towards the continent. As the sea level rose until its maximum, there was a flood of the coastal plain in many parts, separating some Armação dos Búzios areas in two different parts (at Ferradura lake and Tucuns), and the beaches acquired more accentuated crevices. Dias (2009) had already suggested the separation of Búzios around Tucuns, after 6,335-5,574 cal yr BP, when the sea was $2.0 \mathrm{~m}$ above the present level.

Concerning Ferradura, Freitas (2011) reported the occurrence of mangrove vegetation in $5,890 \mathrm{cal} \mathrm{yr} \mathrm{BP}$. The author also classified the other dating as belonging to a lagoon (5,456-4,902 cal yr BP; 5,440-4,967 cal yr BP; 5,301$4,865 \mathrm{cal} \mathrm{yr} \mathrm{BP})$, proving the establishment of a paleolagoon at that time, due to the presence of marine palynomorphs and plant fragments that are characteristic of lagoon environments. The sea level started to fall, after reaching its maximum, as seen in curve built. Moreover, there is no report of shell deposits younger than 5,000 years in the region, which means that after the maximum some lagoons suffered desiccation.

\subsubsection{Phase 3: Sea level fall $(4,500 \mathrm{cal}$ yr BP to the present)}

After the transgressive maximum, the MSL began to decrease to the current one. Manguinhos bight barrier and shorelines migrated towards the ocean to take their actual position. The corresponding paleolagoon of this area suffered dryness. In addition, Ferradura paleolagoon began to stop having connection with the sea (Fig. 6.5) to become the current lake (Fig. 6.6). In other places, marsh areas were formed.

According to Freitas (2011), Ferradura paleolagoon began to suffer confinement since 4,410 cal yr BP, becoming a lake since 2,810 cal yr BP. The author also presented a date, 4,078-3,823 cal yr BP, from samples classified as lagoonal and even being newer than the beginning of that stage. It is possible to suggest the existence of Ferradura paleolagoon in 3,823 cal yr BP. Other areas, where the plain was flooded, were not connected with the sea any longer due to the sea level decline and they experienced dryness. In some cases, marshes were formed, besides the establishment of sand ridges. Shallower lagoons had their reflecting water reduced.

\section{Conclusion}

The curve proposed for Cabo Frio, Arraial do Cabo and Armação dos Búzios region, based on 21 paleolevels, indicates that the sea exceeded the current zero in approximately 6,300 cal $\mathrm{yr} \mathrm{BP}$ and the transgressive maximum occurred in 4,700-4,500 cal yr BP, reaching about $2.4 \mathrm{~m}$ above the current.

The evolutionary model proposed in this work for Armação dos Búzios, divided into 3 phases, is in agreement with the geological map of Martin et al. (1997) and with the distribution of Holocenic deposits.

The use of DGPS technique provided accuracy when associated with processing information from altitudes of indicators, determining their orthometric height and thus reducing errors in the construction of sea level changes graphs. Vermetids (subfossils) reliably and accurately indicate older sea levels, where the gastropods may have their height calibrated according to the local hydrodynamics, with error rate of $\pm 0.5 \mathrm{~m}$ in more sheltered areas and $\pm 1.0 \mathrm{~m}$ in more exposed ones.

For future research, we recommend the study of the mollusk assemblages that occur together with subfossil vermetids, under the concept of potential sea level changes. It is also important to explore subsurface rocky cliff and islets for sessile bioindicators.

This paper contributes to understand the genesis and evolution of the studied coastal plains and archaeological sites distribution (shell middens), which followed the sea level variations; since those shell middens occurs near the coastline.

\section{Acknowledgments}

The authors would like to thank Brazilian financial agencies CNPq (Conselho Nacional de Desenvolvimento Científico e Tecnológico), CAPES (Coordenação de Aperfeiçoamento de Pessoal de Nível Superior) and FAPERJ (Fundação Carlos Chagas Filho de Amparo à Pesquisa do Estado do Rio de Janeiro, E-26/110.138/2014) for their support. This research could not have been accomplished without the assistance of some people: Rudiger Bieler, Renato Guimarães, Jackson Resende, Catia Fernandes Barbosa and Alberto Luis da Silva.

\section{References}

Alves, E., Macario, K., Souza, R., Pimenta, A., Douka, K., Oliveira, F., Chanca, I., Suguio, K., 2015. Radiocarbon Reservoir corrections on the Brazilian coast from pre-bomb marine shells. Quaternary Geochronology, 29, 30-35. doi: 10.1016/j.quageo.2015.05.006. 
Angulo, R..J., Souza, M., 2014. Revisão conceitual de indicadores costeiros de paleoníveis marinhos quaternários no Brasil. Quaternary and Environmental Geosciences, 05 (2), 01-32.

Angulo, R.J., Souza, M.C., Campos, T.F.C., Bezerra, F.H.R., Fernandes, L.A., Giannini, P.C.F., Pitombo, F.B., Veiga, F.A., 2013. Evidence for Late Quaternary episodic uplift of the São Pedro and São Paulo Archipelago, Equatorial Atlantic. Quaternary International, 317, 102-111. doi: 10.1016/j.quaint.2013.06.023

Angulo, R.J., Lessa, G.C., Souza, M.C. de, 2006. A critical review of mid-to late-Holocene sea-level fluctuations on the eastern Brazilian coastline. Quaternary Science Reviews, 25, 486-506.

Angulo, R.J., Pessenda, L.C.R., Souza, M.C., 2002. O significado das datações ao ${ }^{14} \mathrm{C}$ na reconstrução de paleoníveis marinhos e na evolução das barreiras quaternárias do litoral paranaense. Revista Brasileira de Geociências, 32 (1), 95-106.

Angulo, R.J., Giannini, P.C.F., Suguio, K., Pessenda, L.C.R., 1999. Relative sea-level changes in the last 5500 years in southern Brazil (Laguna - Imbituba region, Santa Catarina state) based on vermetid ${ }^{14} \mathrm{C}$ ages. Marine Geology, 159, 323-339.

Angulo, R.J., Lessa, G.C., 1997. The Brazilian sea-level curves: a critical review with emphasis on the curves from the Paranaguá and Cananéia regions. Marine Geology, 140, 141-166.

Antonioli, F., Chemello, R., Improta, S., Riggio, S., 1999. Dendropoma lower intertidal reef formations and their palaeoclimatological significance, NW Sicily. Marine Geology, 161, 155-170.

Ascough, P.L., Cook, G.T., Dugmore, A.J., 2005. Methodological approaches to determining the marine radiocarbon reservoir effect. Progress in Physical Geography. 29, 532-547.

Baker, R.G.V., Haworth, R.J., 2000. Smooth or oscillating late Holocene sea-level curve? Evidence from cross-regional statistical regressions of fixed biological indicators. Marine Geology, 163, 353-365. doi: 10.1016/S0025-3227(99)00117-6.

Bandel, K., Kiel, S., 2000. Earliest known (Campanian) members of the Vermetidae, Provannidae and Litiopidae (Cerithioidea, Gastropoda), and a discussion of their possible relationships. Mitteilungenausdem Geologisch-PaläontologischenInstitut der Universität Hamburg, 84, 209-218.

Barbiére, E.B., 1984. Cabo Frio e Iguaba Grande, dois microclimas distintos a um curto intervalo espacial. In: Lacerda, L.D. de, Araújo, D.S.D., Cerqueira, R.,Turcq, B. (Orgs.) Restingas: Origem, Estrutura, Processos. CEUFF. Niterói, 3-13.

Beaman, R., Larcombe, P., Carter, R.M., 1994. New evidence for the Holocene sealevel high from the inner shelf, Central Great Barrier Reef, Australia. Journal of Sedimentary Research, 64 (4a), 881-885.

Behre, K-E., 2007. A new Holocene sea-level curve for the southern North Sea. Boreas,36, 82-102. doi: 10.1111/j.15023885.2007.tb01183.x.

Bieler, R., Petit, R.E., 2011. Catalogue of Recent and Fossil "Worm-Snail" Taxa of the Families Vermetidae, Siliquariidae, and Turritellidae (Mollusca: Caenogastropoda). Zootaxa, 2948, 1-103.
Breves-Ramos, A., 2012. Distribuição da malacofauna e estrutura populacional de Isognomon bicolor e Myoforceps aristatus em agregados de Petaloconchus varians (Gastropoda: Vermetidae) na Baía da Ilha Grande (Rio de Janeiro-Brasil). Doctoral thesis. Programa de Pós-Graduação em Ciências Biológicas (Zoologia), Universidade Federal do Rio de Janeiro/Museu Nacional, Rio de Janeiro, 237 p.

Bronk Ramsey, C., 1995. Radiocarbon Calibration and Analysis of Stratigraphy: The OxCal Program. Radiocarbon, 37 (2), 425430.

Bruun, P., 1962. Sea level rise as a cause of shore erosion. Journal of Waterways and Harbors Division, 88, 117-130.

Bungenstock, F., Weerts, H.J.T., 2010. The high-resolution Holocene sea-level curve for Northwest Germany: global signals, local effects or data-artefacts? International Journal of Earth Sciences, 99 (8), 1687-1706. doi: 10.1007/s00531-0090493-6.

Carmo, R.B., 2014. Mapeamento detalhado da porção aflorante de beachrocks em Jaconé (Maricá e Saquarema, RJ) em vistas de sua Geoconservação. Specialization thesis. Programa de PósGraduação em Geologia do Quaternário, Universidade Federal do Rio de Janeiro/Museu Nacional, Rio de janeiro, $51 \mathrm{p}$.

Castro, J.W.A., Suguio, K., Seoane, J.C.S., Cunha, A.M., Dias, F.F., 2014. Sea-level fluctuations and coastal evolution in the state of Rio de Janeiro, southeastern Brazil. Anais da Academia Brasileira de Ciências, 86 (2), 671-683. Doi: 10.1590/00013765201420140007.

Castro, J.W.A., Suguio, K., Cunha, A.M., Guedes, E., Tâmega, F.T.S., Rodriguez, R.R., 2012. Rochas de Praia (Beachrocks) da Ilha do Cabo Frio, Arraial do Cabo: Registro Geológico ímpar da Transição Pleistoceno - Holoceno no Estado do Rio de Janeiro. Anuário do Instituto de Geociências - UFRJ, 35 (1), 236-241.

Castro, J.W.A., Suguio, K., 2011. Rochas de praia "beach rocks" testemunhos de antigas posições do nível relativo do mar na Ilha do Cabo Frio (Arraial do Cabo) Estado do Rio de Janeiro: registro local da transição Pleistoceno - Holoceno. XIII Congresso da Associação Brasileira de Estudos do Quaternário - ABEQUA. Armação dos Búzios, RJ, 5 p.

Cavallotto, J.L., Violante, R.A., Parker, G., 2004. Sea-level fluctuations during the last 8600 years in the de la Plata river (Argentina). Quaternary International, 114, 155-165. doi: http://dx.doi.org/10.1016/S1040-6182(03)00050-8.

Chappell, J., 1983. Evidence for a smoothly falling sea level relative to north Queensland. Nature, 302, 406-408.

Cunha, A.L., Castro, J.W. de A., Dias, F.F., 2012. A Importância da Preservação das Acumulações Bioclásticas da Planície Costeira do Rio Una, Municípios de Cabo Frio e Armação dos Búzios, RJ, Brasil. Anuário do Instituto de Geociências UFRJ, 35 (1), 58-67.

Dasgupta, S., Meisner, C., 2009. Climate Change and Sea Level Rise - A Review of the Scientific Evidence. Environment Department Papers. Climate Change Series, 118, 36 p.

Dias, F.F., 2009. Variações do Nível Relativo do Mar na Planície Costeira de Cabo Frio e Armação dos Búzios - RJ: 
Reconstrução Paleoambiental Holocênica e Cenários Futuros. Doctoralthesis. Programa de Pós-Graduação em Geologia, Universidade Federal do Rio de Janeiro, Rio de Janeiro, 145 p.

Dominguez, J.L.M., Bittencourt, A.C.S.P., Leão, Z.N.A.M., Azevedo, A.E.G., 1990. Geologia do Quaternário costeiro do Estado de Pernambuco. Revista Brasileira de Geociências, 20 (1-4), 208-215.

Flood, P.G., Frankel, E., 1989. Late Holocene higher sea level indicators from eastern Australia. Marine Geology, 90, 193195.

Freitas, A.G., 2011. Registro palinológico e mudanças ambientais holocênicas na península de Armação dos Búzios, Região dos Lagos - RJ, Brasil. Doctoral thesis. Programa de PósGraduação em Geologia, Universidade Federal do Rio de Janeiro, Rio de Janeiro, 142 p.

Grossman, E.E., Fletcher, C.H., 1998. Sea level higher than present 3500 years ago on the Northern Main Hawaiian Islands. Geology, 26 (4), 363-36.

IBGE - Instituto Brasileiro de Geografia e Estatística, 2014. Banco de Dados Geodésicos [online]. Available in: <http://www.ibge.gov.br/home/geociencias/geodesia/bdgp esq_googlemaps.php?estacao $=91970 \&$ tipo_estacao $=\& u f=\# t$ abela_dados >. Consulted on: January, 2017.

Isla, F.I., 1989. Holocene sea-level fluctuation in the Southern Hemisphere. Quaternary Science Reviews, 8, 359-368.

Kampel, M., 2002. Sensoriamento Remoto Aplicado à Oceanografia. Ministério da Ciência e Tecnologia. Instituto Nacional de Pesquisas Espaciais - INPE. São José dos Campos, 6, $31 \mathrm{p}$.

Kaye, C.A., Barghoorn, E.S., 1964. Late Quaternary Sea-Level Change and Crustal Rise at Boston, Massachusetts, with Notes on the Auto compaction of Peat. Geological Society of America Bulletin, 75, 63-80.

Keen, A.M., 1961. A proposed reclassification of the gastropod family Vermetidae. Bulletin of the British Museum (Natural History) Zoology, 7, 183-213.

Kelley, J.T., Belknap, D.F., Kelley, A.R., Claesson, S.H., 2013. A model for drowned terrestrial habitats with associated archeological remains in the northwestern Gulf of Maine, USA. Marine Geology, 338, 1-16. doi: 10.1016/j.margeo.2012.10.016.

Laborel, J., Laborel-Deguen, F., 1996. Biological indicators of Holocene sea-level and climatic variations on rocky coasts of tropical and subtropical regions. France Quaternary International, 31, 53-60.

Laborel, J., Laborel-Deguen, F., 1994. Biological indicators of relative sea-level variation and of co-seismic displacements in the Mediterranean area. Journal of Coastal Research, 10 (2), 395415.

Laborel, J., 1986. Vermetids gastropods as sea-level indicators. In: van de Plassche, O. (Ed.) Sea-Level Research: A Manual for the Collection and Evaluation of Data. Geo Books, Norwich, 281-310.

Laborel, J., 1977. Are Reef-Building Vermetids Disappearing in the South Atlantic? Proceedings. Third International Coral Reef Symposium, 3, 233-236.
Lambeck, K., Antonioli, F., Purcella, A., Silenzi, S., 2004. Sealevel change along the Italian coast for the past 10,000 yr. Quaternary Science Reviews, 23, 1567-1598. doi: 10.1016/j.quascirev.2004.02.009.

Lambeck, K., Woodroffe, C.D., Antonioli, F., Anzidei, M., Gehrels, W.R., Laborel, J., Wright, A.J., 2010. Paleoenvironmental Records, Geophysical Modeling, and Reconstruction of Sea-Level Trends and Variability on Centennial and Longer Timescales. In: Church, J.A., Woodworth, P.L., Aarup, T., Wilson, S. (Eds), 2010, 61-121.

Lewis, S.E., Sloss, C.R., Murray-Wallace, C.V., Woodroffe, C.D., Smithers, S.G., 2013. Post-glacial sea-level changes around the Australian margin: a review. Quaternary Science Reviews, 74, 115-138.

Macario, K.D., Oliveira, F.M., Carvalho, C., Santos, G.M., Xu, X., Chanca, I.S., Eduardo, Q. Alves, Jou, R.M., Oliveira, M.I., Pereira, B.B., Moreira, V., Muniz, M.C., Linares, R., Gomes, P.R.S., Anjos, R.M., Castro, M.D., Anjos, L., Marques, A.N., Rodrigues, L.F., 2015. Advances in the graphitization protocol at the Radiocarbon Laboratory of the Universidade Federal Fluminense (LAC-UFF) in Brazil. Nuclear Instruments and Methods in Physics Research Section B: Beam Interactions with Materials and Atoms, 361, 402-405.

Macario, K.D., Gomes, P.R.S., Anjos, R.M., Carvalho, C., Linares, R., Alves, E.Q., Oliveira, F.M., Castro, M.D., Chanca, I.S., Silveira, M.F.M., Pessenda, L.C.R., Moraes, L.M.B., Campos, T.B., Cherkinsky, A., 2013. The Brazilian AMS Radiocarbon Laboratory (LAC-UFF) and the Intercomparison of Results with CENA and UGAMS. Radiocarbon, 55, 325-330. doi: 10.2458/azu_js_rc.55.16300.

Mansur, K.L., Ramos, R.R.C., Godoy, J.M.O., Nascimento, V.M.R., 2011. Beachrock de Jaconé, Maricá e Saquarema - RJ: importância para a história da Ciência e para o conhecimento geológico. Revista Brasileira de Geociências, 41 (2), 290-303.

Martin, L., Suguio, K., Domingues, J.M., Flexor, J.M., 1997. Geologia do Quaternário costeiro do Litoral Norte do Rio de Janeiro e Espírito Santo. CPRM, Belo Horizonte, 112 p.

Martin, L., Suguio, S., 1992. Variation of coastal dynamics during the last 7000 years recorded in beach-ridge plains associated with river mouths: example from the central Brazilian coast. Palaeogeography, Palaeoclimatology, Palaeoecology, 99, 119140.

Martin, L., Suguio, K., 1975. The State of São Paulo coastal marine Quaternary Geology: The ancient strand lines. Anais da Academia Brasileira de Ciências, 47, 249-263.

Martinez, S., Rojas, A., 2013. Relative sea level during the Holocene in Uruguay. Palaeogeography, Palaeoclimatology, Palaeoecology, 374, 123-131. doi: 0.1016/j.palaeo.2013.01.010.

Matsushina, Y., Sugimura, A., Berryman, K., Ishii, T., Maeda, Y., Matsumoto, E., Yonekura, N., 1984. Holocene sea-level changes in Fiji and Western Samoa. In: Sugimura, A. (ed.), Sea level changes and tectonics in the Middle Pacific, HIPAC Team, Kobe, 137-185.

Mesquita, A.R. de, Leite, J.B.A., Rizzo, R., 1979. Contribuição ao estudo das correntes marinhas na plataforma entre Cabo Frio 
e Cananéia. Boletim do Instituto de Oceanografia, 28 (2), 95100.

Morais, R.M.O, Mello, C.M., Costa, F.O, Santos, P.F., 2006. Fácies Sedimentares e Ambientes Deposicionais Associados aos Depósitos da Formação Barreiras no Estado do Rio de Janeiro. Revista do Instituto de Geociências - USP. Geologia USP Série Científica, São Paulo, 6 (2), 19-30.

Mörner, N-A, 1984. Differential Holocene Sea Level Changes Over the Globe: Evidence for Glacial Eustasy and Crustal Movements. Litoralia, 1 (1), 83-86.

Nakada, M., Yonekura, N., Lambeck, K., 1991. Late Pleistocene and Holocene sea-level changes in Japan: implications for tectonic histories and mantle rheology. Palaeogeography, Palaeoclimatology, Palaeoecology, 85, 107-122.

Nimer, E., 1989. Climatologia do Brasil. Secretaria de Planejamento e Coordenação da Presidência da República e IBGE, Rio de Janeiro, 421 p.

Pirazzoli, P.A., Laborel, J., Stiros, S.C., 1996. Earthquake clustering in the eastern Mediterranean during historical times. Journal of Geophysical Research, 101, 6083-6097. doi: 10.1029/95JB00914.

Pirazzoli, P.A., 1991. A Survey of Relative Sea-Level Changes Observed During the Holocene. Glacial Isostasy, Sea-Level and Mantle Rheology, 334, 259-269.

Ramsay, P.J. and Cooper, J.A.G., 2002. Late Quaternary sea-level change in South Africa. Quaternary Research, 57, 82-90.

Reimer, P.J., Bard, E., Bayliss, A., Beck, J.W., Blackwell, P.G., Bronk Ramsey, C., Grootes, P.M., Guilderson, T.P., Haflidason, H., Hajdas, I., Hatt, C., Heaton, T.J., Hoffmann, D.L., Hogg, A.G., Hughen, K.A., Kaiser, K.F., Kromer, B., Manning, S.W., Niu, M., Reimer, R.W., Richards, D.A., Scott, E.M., Southon, J.R., Staff, R.A., Turney, C.S.M., van der Plicht, J., 2013. IntCal13 and Marine13 Radiocarbon Age Calibration Curves 0-50,000 years cal BP. Radiocarbon, 55 (4), 1869-1887.

Ribeiro, P.C., Giannini, P.C.F., Nascimento Junior, D.R., Sayeg, I.J., 2011. Vermetídeos fósseis em costões rochosos de Guarapari, ES: distribuição espacial, morfologia, mineralogia e 818O. XIII Congresso da Associação Brasileira de Estudos do Quaternário - ABEQUA. Armação dos Búzios, RJ, 5 p.
Safriel, U.N., 1975. The role of vermetid gastropods in the formation of Mediterranean and Atlantic reefs. Oecologia, 20, 85-101. doi: 10.1007/BF00364323.

Savi, D.C., 2007. Erosão e Acresção Costeira na Enseada dos Anjos, Arraial do Cabo, RJ. Revista Brasileira de Geofísica, 25 (Supl. 1), 91-99.

Sloss, C.R., Murray-Wallace, C.V., Jones, B.G., 2007. Holocene sea-level change on the southeast coast of Australia: a review. The Holocene, 17 (7), 999-1014.

Spotorno, P., Tâmega, F.T.S., Bemvenuti, C.E., 2012. An overview of the recent vermetids (Gastropoda: Vermetidae) from Brazil. Strombus, 19 (1-2), 1-8.

Stuiver, M., Pearson, G.W., Braziunas, T., 1986. Radiocarbon age calibration of marine samples back to 9000 calyr BP. Radiocarbon 28 (2B), 980-1021.Suguio, K., Martin, L., Bittencourt, A.C.S.P., Dominguez, J.M.L., Flexor, J-M., Azevedo, A.E.G., 1985. Flutuações do nível relativo do mar durante o Quaternário superior ao longo do litoral brasileiro e suas implicações na sedimentação costeira. Revista Brasileira de Geociências, 15 (4), 273-286.

Suguio, K., Martin, L., Bittencourt, A.C.S.P., Dominguez, J.M.L., Flexor, J-M., Azevedo, A.E.G., 1985. Flutuações do nível relativo do mar durante o Quaternário superior ao longo do litoral brasileiro e suas implicações na sedimentação costeira. Revista Brasileira de Geociências, 15 (4), 273-286.

Suguio, K., Barreto, A.M.F., Oliveira, P.E., Bezerra, F.H.R., Vilela, M.C.S.H., 2013. Indicators of Holocene sea level changes along the coast of the states of Pernambuco and Paraíba, Brazil. Geologia USP, Sériecientífica, 13 (4), 141-152. doi: 10.5327/Z1519-874X201300040008.

Van Andel, T.H., Laborel, J., 1964. Recent high sea-level stand near Recife, Brazil. Science, 145 (5), 80-81.

Vescogni, A., Bosellini, F.R., Reuter, M., Brachert, T.C., 2008. Vermetid reefs and their use as palaeobathymetric markers: New insights from the Late Miocene 175 of the Mediterranean (Southern Italy, Crete). Palaeogeography, Palaeoclimatology, Palaeoecology, 267, 89-101.

Williams, S.J., 2013. Sea-level rise implications for Costal Regions. Journal Coastal Research, 63, 184-196. doi: 10.2112/SI63015.1 